\title{
Occurrence of lipofuscin in inherited metabolic disorders affecting the nervous system
}

\author{
KRISTER KRISTENSSON AND PATRICK SOURANDER
}

From the Neuropathological Laboratory, Department of Pathology I, University of Gothenburg, Sweden

According to Björkerud (1964), the lipofuscin granules may be described as intracellular entities defined by their structural, histochemical, and physical properties on the light microscopic level. They are characterized by, for example, yellowish primary fluorescence, poor solubility, acid-fastness, and stainability with the periodic-acid-Schiff method (McManus, Hotchkiss) and Sudan black B. The occurrence of lipofuscin in various organs, including the brain, is associated with the process of ageing (Obersteiner, 1912; Gellerstedt, 1933; Hamperl, 1934; Strehler, Mark, Mildvan, and Gee, 1959; Brody, 1960) and starts very early, in fact in childhood. There are also, however, several reports on an increase in lipofuscin or ceroid, which, according to Pearse (1960), represents a typical lipofuscin in an early stage of oxidation, particularly in the brain and liver, in several diseases (Bachmann, 1953; Björkerud and Schelin, 1964; Wolman, 1964; Gilles, 1965). An increase of lipofuscin in animal tissues has also been found in various experimental conditions (Einarson and Telford, 1960; Sulkin and Srivanij, 1960; Ashford and Porter, 1962; Neglia, Burrows, Thompson, and Schaffner, 1963).

Our interest in lipofuscin was evoked by the finding of large amounts of lipofuscin not only in the central nervous system but also in various visceral organs in juvenile amaurotic idiocy (Batten-Spielmeyer-Vogt disease). As this disease is supposed to be due to a genetically determined metabolic disorder, it would be interesting to study the occurrence of lipofuscin in other inherited metabolic diseases, particularly those involving the nervous system.

\section{MATERIAL AND METHODS}

The material consisted of necropsy specimens from one case of Niemann-Pick disease, two cases of Gaucher's disease (one of the infantile, the other of the juvenile type), two cases of metachromatic leucodystrophy, one case of globoid body leucodystrophy (Krabbe's disease), one case of infantile amaurotic idiocy (Tay-Sachs disease), and three cases of juvenile amaurotic idiocy (Batten-Spielmeyer-Vogt disease). These cases were histologically examined by one of us (P. Sourander) and

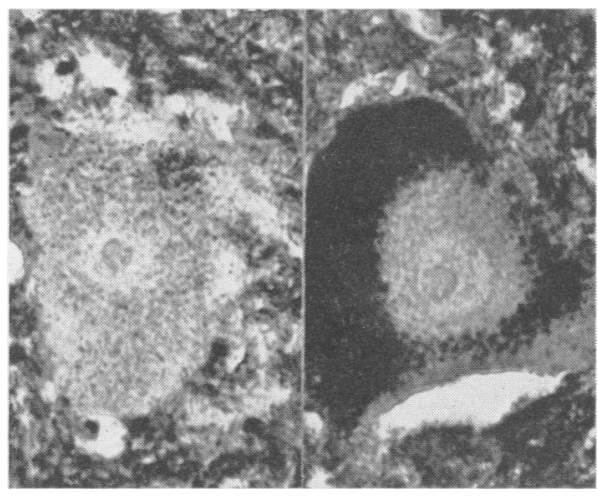

FIG. 1a.

FIG. $1 \mathrm{~b}$.

FIG. 1a. Nerve cell showing pigment granules scattered in the cytoplasm. Group II cell. Sudan black B.

FIG. 1b. Nerve cell showing aggregation of pigment granules in the cytoplasm. Group III cell. Sudan black B.

biochemically investigated by Dr. L. Svennerholm (Table I). As controls, brains were examined from three patients 15,15 , and 30 years of age, and visceral organs from four patients $13,15,15$, and 32 years of age. These specimens were obtained from coroner's necropsies following sudden death.

The tissues were fixed in a $10 \%$ neutral formalin solution. Blocks were obtained from the frontal lobe of the brain, the medulla oblongata, cerebellum, heart, liver, and spleen. Paraffin sections were used for staining with long Ziehl-Neelsen, periodic-acid-Schiff (P.A.S.) according to McManus's method, and Sudan black B. Deparaffined sections mounted in glycerol were examined by fluorescence microscopy at 3,650 §.

According to Brody, the greatest amount of lipofuscin in cortical neurones, when present, is located in layer III. Consequently this layer was chosen for study. A semiquantitative method described by Brody (1960) was used for the estimation of lipofuscin deposition within the neurones. According to this method, the neurones are divided into three groups: I no pigment, II scattered pigment, III aggregation of pigment in the cytoplasm (Fig. 1). Percentages were calculated after the examination of 500 neurones in P.A.S.-stained sections in each case. The lipofuscin content of visceral organs was graded from 0 to +++ . 
TABLE I

CLINICAL SUMMARIES RELATED TO NECROPSY FINDINGS

\begin{tabular}{|c|c|c|c|c|}
\hline \multirow[b]{2}{*}{ Disease } & \multirow[b]{2}{*}{$\begin{array}{l}\text { Age at } \\
\text { Onset }\end{array}$} & \\
\hline & & $\begin{array}{l}\text { Age at } \\
\text { Death }\end{array}$ & Cause of Death & Stored Substance \\
\hline Niemann-Pick & - & $8 \mathrm{mth}$. & Circulatory insufficiency & Sphingomyelin \\
\hline Gaucher infantile & - & $5 \frac{1}{2}$ yr. & Respiratory infection & Glucocerebroside \\
\hline Gaucher juvenile & - & $16 \mathrm{yr}$. & Bronchopneumonia & Glucocerebroside \\
\hline $\begin{array}{l}\text { Metachromatic } \\
\text { leucodystrophy }\end{array}$ & $1 \mathrm{yr}$. & 3 yr. $10 \mathrm{mth}$. & Sepsis & Sulphatide \\
\hline $\begin{array}{l}\text { Metachromatic } \\
\text { leucodystrophy }\end{array}$ & $1 \mathrm{yr}$. & $2 \frac{1}{2} \mathrm{yr}$ & Bronchopneumonia & Sulphatide \\
\hline Krabbe & $4 \mathrm{mth}$. & 1 yr. $4 \mathrm{mth}$. & Respiratory infection & $\begin{array}{l}\text { Cerebroside in } \\
\text { globoid bodies }\end{array}$ \\
\hline Tay-Sachs & $6 \mathrm{mth}$. & 4 yr. & Bronchopneumonia & Ganglioside $\left(G_{M_{2}}\right)$ \\
\hline Batten-Spielmeyer-Vogt & $4 \mathrm{yr}$. & $16 \mathrm{yr}$. & Pneumonia & Lipofuscin \\
\hline Batten-Spielmeyer-Vogt & 5 yr. & $22 \mathrm{yr}$. & Sepsis & Lipofuscin \\
\hline Batten-Spielmeyer-Vogt & $7 \mathrm{yr}$. & $21 \mathrm{yr}$. & Pneumonia & Lipofuscin \\
\hline
\end{tabular}

Main Pathological Findings in Organs Examined

Niemann-Pick cells in spleen, liver; storage in ballooned os subcortical nerve cells Gaucher cells in spleen, liver, $\stackrel{\overbrace{}}{\supset}$ cerebral cortex and white matter Gaucher cells in spleen, liver, $<$ cerebral cortex and white $\vec{F}$ matter Metachromatic granules in cerebral white matter, dentate nucleus, and histocytes of the $\bar{O}$ liver

Metachromatic granules in $\vec{\nabla}$ cerebral white matter, dentate $\varrho$ nucleus, and histocytes of the

Globoid bodies in cerebral $\vec{\theta}$ white matter

Storage in ballooned nerve cells, glia, and macrophages. $\vec{\omega}$ Vacuolated histocytes Storage in nerve cells, glia, and macrophages; similar storage in heart, spleen, and liver Storage in nerve cells, glia, and $\mathcal{N}$ macrophages; similar storage in heart, spleen, and liver $O$ Storage in nerve cells, glia, an $\overrightarrow{\vec{\omega}}$ macrophages; similar stora $\vec{\omega}$ in heart, spleen, and liver

\section{RESULTS}

There was good agreement between the amounts of lipofuscin revealed by the different staining methods and fluorescence microscopy. The results are listed in Table II and Fig. 2. The amount of lipofuscin in the control cases closely paralleled that found by Brody in his study of deposition of lipofuscin in the human cerebral cortex. The very small amount of lipofuscin found in the myocardium in the control cases was in accordance with the findings of Strehler ct al. (1959) in a study of pigment accumulation in human myocardium.

Only the juvenile cases of amaurotic idiocy

TABLE II

AMOUNT OF LIPOFUSCIN FOUND AT NECROPSY

\begin{tabular}{llll} 
Disease & Heart & Liver & Spleen \\
\hline $\begin{array}{l}\text { Niemann-Pick } \\
\text { Gaucher infantile }\end{array}$ & - & - & - \\
$\begin{array}{l}\text { Gaucher juvenile } \\
\text { Metachromatic leucodystrophy }\end{array}$ & - & - & - \\
$\begin{array}{l}\text { Krabbe } \\
\text { Tay-Sachs }\end{array}$ & - & - & - \\
$\begin{array}{l}\text { Batten-Spielmeyer-Vogt } \\
\text { Control cases }\end{array}$ & -+++ & + & - \\
$\quad+$ moderate amounts & $-(+)$ & $-(+)$ & $+(+)$ \\
++ large amounts & & & ++ \\
+++ very large amounts & & &
\end{tabular}

showed a definite increase of lipofuscin in the cortic neurones (Fig. 3b). In the juvenile case of Gauchers. $\overrightarrow{0}$ disease there appeared to be a slight increase, but th method does not seem to permit any definite conclusions. In the nerve cells of the inferior olive, a large amount of lipofuscin was also seen in the infantile case of amaurotic idiocy (Fig. 4a). In the nerve cells of the dentate nucleus, large amounts of lipofuscin were found not only in the infantile and $\odot$ juvenile cases of amaurotic idiocy, but also in the $\overrightarrow{\overrightarrow{0}}$ two cases of metachromatic leucodystrophy, while 3 only scanty amounts were found in the control cases.

In juvenile amaurotic idiocy the glial cells and macrophages contained large amounts of lipofuscin. This was also seen in the infantile form even in the cerebral cortex, where the nerve cells contained only scanty amounts (Fig. 3a). Lipofuscin occurred pro- 3 . fusely in the glial cells and macrophages of the white $\delta$ matter in the two cases of metachromatic leuco- $₹$ dystrophy (Fig. 4b) and in smaller amounts in $\frac{\mathrm{O}}{\mathrm{b}}$ scattered areas of the cerebral white matter in the case of globoid body leucodystrophy.

In the cases of juvenile amaurotic idiocy large amounts of lipofuscin were found in the myo- $\sigma$ cardium, liver (Fig. 5b), and spleen. In the infantile $N$ form moderate amounts were found in reticulo- $\mathbb{W}_{\mathrm{W}}$ histiocytic cells of the spleen (Fig. 5a) and liver. In 


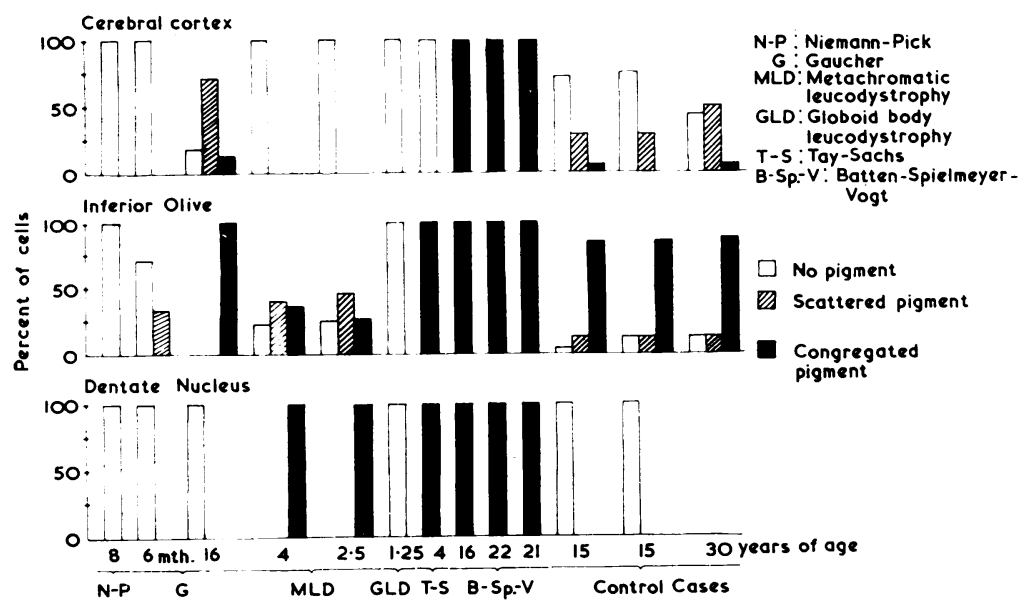

FIG. 2. Histogram illustrating amounts of lipofuscin in the cerebral cortex, the inferior olive, and the dentate nucleus in the diseases studied.

the other cases no increase of lipofuscin was found in the visceral organs examined.

\section{DISCUSSION}

No definite conclusion has, as yet, been reached concerning the genesis and nature of lipofuscin. Findings have been presented as indicating a functional role of these granules in the neuronal metabolism during ageing (Hyden and Lindström, 1950; Hydén, 1960) or signifying neurosecretory activity (Issidorides and Shanklin, 1961). However it has also been suggested that lipofuscin is merely a degradation product of lipids, the yellow auto-fluorescence being due to polymerized unsaturated fatty acids (Pearse,
1960; Friede, 1962; Gedigk and Pioch, 1965). The lysosome concept put forward recently suggests that lipofuscin is included in these 'digestive' organelles (Essner and Novikoff, 1960).

Zeman and Albert (1963), using a fluorescence microscope, found no lipofuscin in the cortex of infantile amaurotic idiocy. In the present case of this disease only scanty amounts of lipofuscin were found in the cortical neurones, but large amounts in the glial cells and macrophages. By analogy with electron microscopic studies (Terry and Weiss, 1963; Wallace, Volk, and Lazarus, 1964) it is suggested that this accumulation may reflect a degradation of neuronal lipids occurring in these cells (Eeg-Olofson, Kristensson, Sourander, and Svennerholm, 1966). In 'lipo-

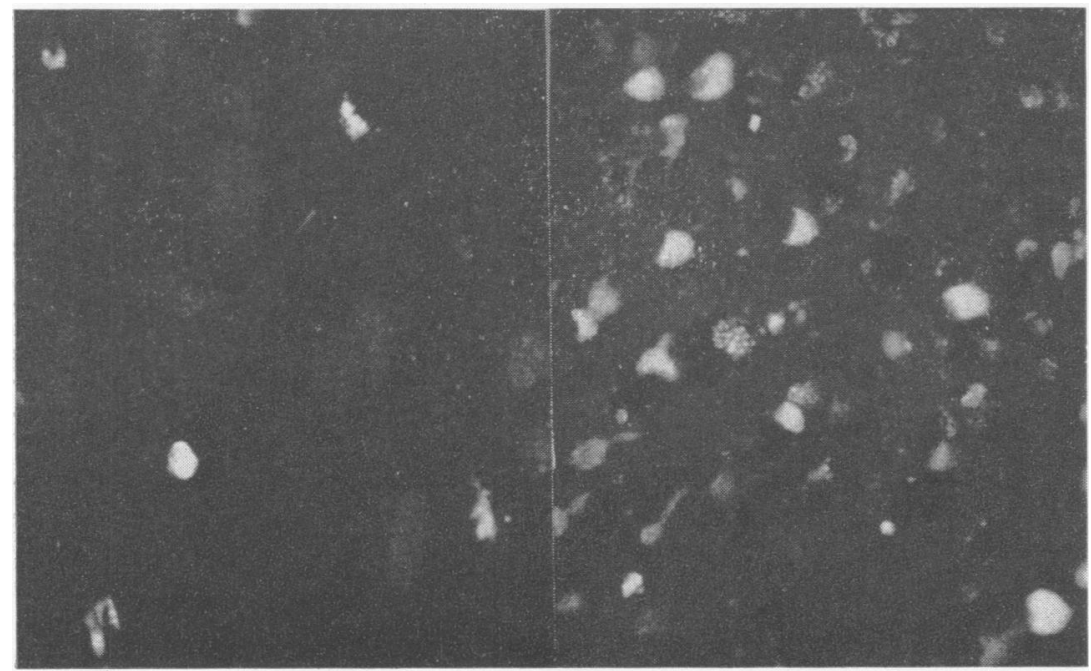

FIG. 3a.
FIG. $3 b$.
FIG. 3a. Infantile amaurotic idiocy. Precentral gyrus showing autofluorescent material in glial cells. The greatly swollen nerve cells contain no or very weakly fluorescent material.

FIG. 3b. Juvenile amaurotic idiocy. Precentral gyrus. Fluorescent material in both nerve and glial cells. 


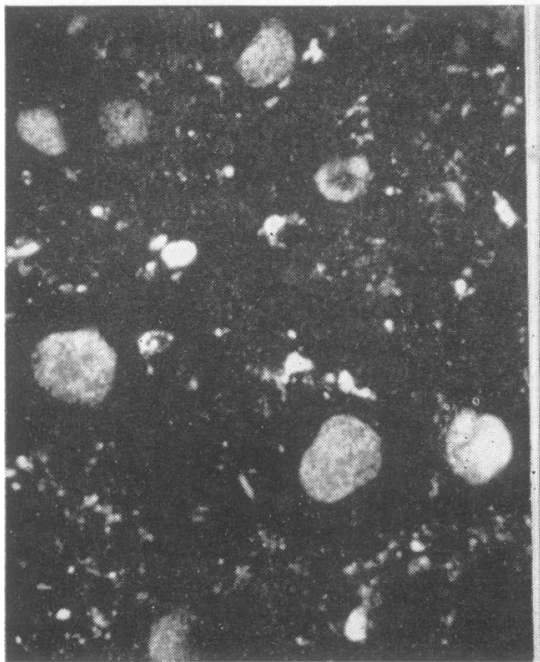

FIG. $4 a$.

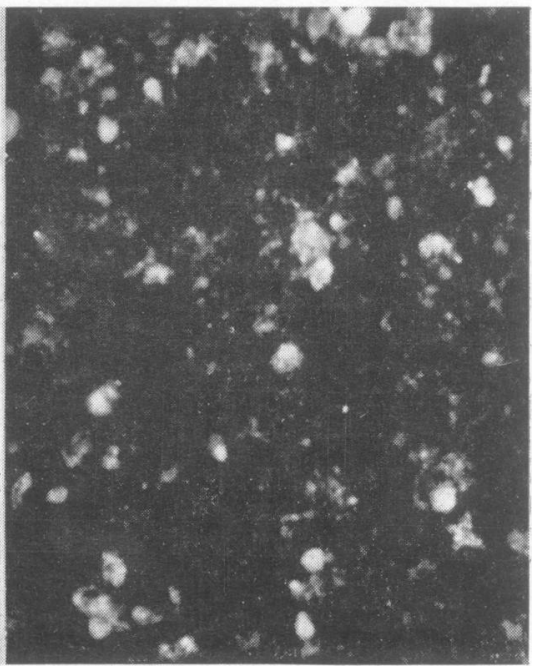

FIG. $4 b$.

FIG. 4a. Infantile amaurotic idiocy. Dentate nucleus. Fluorescent material in both nerve cells and glial cells.

FIG. 4b. Metachromatic leucodystrophy. Cerebellar white matter. Fluorescent material in granular cells.

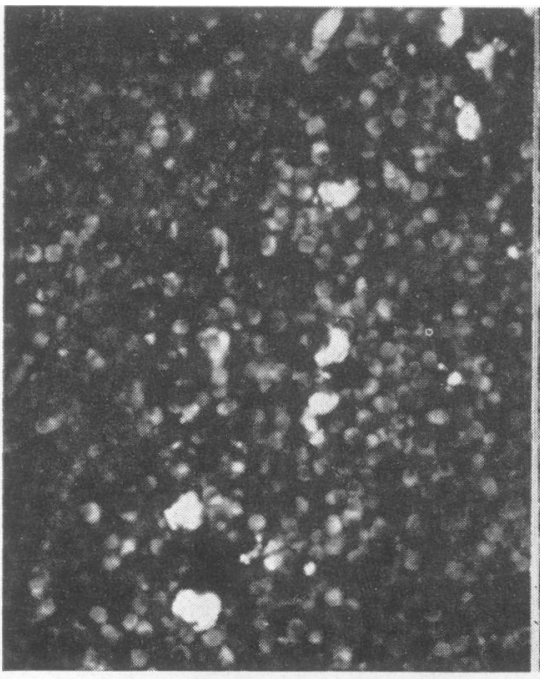

FIG. 5a.

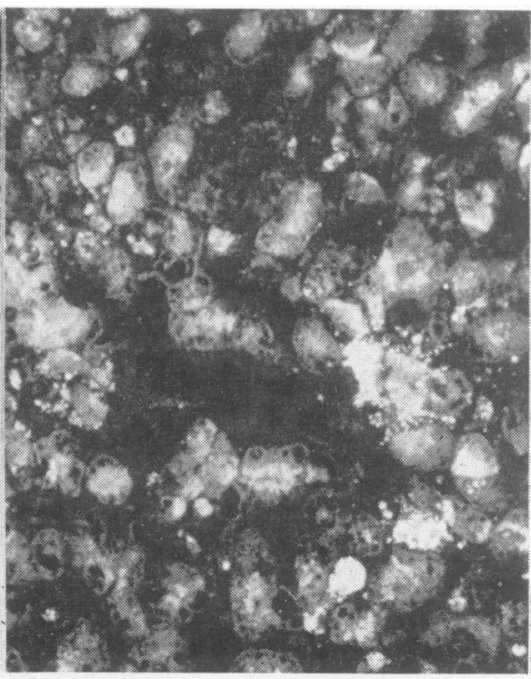

FIG. $5 b$.

FIG. 5a. Infantile amaurotic idiocy. Spleen. Fluorescent material in reticulohistiocytic cells.

FIG. 5b. Juvenile amaurotic idiocy. Liver. Fluorescent material in Kupffer cells and liver parenchymal cells. 
philic nuclei' (Obersteiner, 1912), such as the inferior olive and dentate nucleus, large amounts of lipofuscin were found in the nerve cells, suggesting that degradation of the neuronal lipids may occur in neurones, too. Significant amounts of lipofuscin were also noticed in reticulohistiocytic cells of liver and spleen. It has recently been shown by Svennerholm (Svennerholm and Sourander, 1965; EegOlofson et al., 1966) that the ganglioside stored in the neurones in Tay-Sachs disease also accumulates in these organs. It is possible that a disturbed metabolism of gangliosides may lead to concomitant formation of lipofuscin not only in brain but also in the liver and spleen.

In adult cases of metachromatic leucodystrophy Diezel (1962) observed lipofuscin in granular cells of the white matter. In the present two cases of infantile metachromatic leucodystrophy a great many cells containing lipofuscin were distributed throughout the white matter of the brain. Nerve cells of the dentate nucleus were found to contain both sulphatide and lipofuscin. The occurrence of lipofuscin in some neurones and granular cells in metachromatic leucodystrophy may be explained as a consequence of a disturbed metabolism of glycerophospholipids caused by accumulation of sulphatides. Glycerophospholipids are rich in polyunsaturated fatty acids, which are readily oxidized, polymerized, and finally bound to the tissue structure as lipofuscin (Svennerholm and Sourander, 1965).

it is known from light microscopic studies that lipofuscin accumulates in cortical nerve cells in juvenile amaurotic idiocy (e.g., Sjövall, 1934; Zeman and Albert, 1963). Sjövall compared this accumulation with the process of senile involution and regarded it as a sign of premature ageing of the neurones. Sjövall also found an accumulation of a similar substance in lymph nodes and spleen and suggested that juvenile amaurotic idiocy was a generalized metabolic disorder. The finding of large amounts of lipofuscin in the visceral organs in the present cases of this disease, already described in a previous study (Kristensson, Rayner, and Sourander, 1965), supports this opinion.

In an electron microscopic study of one case of juvenile amaurotic idiocy, Gonatas, Terry, Winkler, Korey, Gomez, and Stein (1963) found in the cytoplasm of neurones and glial cells an increased number of lysosome-like bodies, lipofuscin, and an unusual organelle called a membrano-vesicular body. Intermediate forms, suggestive of transformations from lysosomes to the membrano-vesicular body to lipofuscin, were also seen. These authors assumed that the neuronal accumulation of lipofuscin was secondary to the degradation of a postulated abnormal lipid, with an ultrastructure corresponding to the membrano-vesicular body.

The accumulation of lipofuscin in neurones and cells of visceral organs in juvenile amaurotic idiocy is more pronounced than in any other of the diseases investigated. This may be due partly to the long duration of the disease and partly to the character of the enzymatic lesion(s).

\section{SUMMARY}

The occurrence of lipofuscin in the brain, heart, liver, and spleen was studied in cases of NiemannPick disease, Gaucher's disease, metachromatic leucodystrophy, globoid body leucodystrophy, infantile amaurotic idiocy, and juvenile amaurotic idiocy. Although significant amounts of lipofuscin were found in the cases of infantile amaurotic idiocy and metachromatic leucodystrophy, the cases of juvenile amaurotic idiocy were distinguished by an abundant deposit of lipofuscin in neurones and cells of visceral organs. By analogy with, for example, electron-microscopic studies, it is proposed that the accumulation of lipofuscin may reflect a disturbed degradation of lipids rich in polyunsaturated fatty acids. The significance of the pronounced accumulation of lipofuscin in juvenile amaurotic idiocy is briefly discussed.

\section{REFERENCES}

Ashford, T. P., and Porter, K. R. (1962). Cytoplasmic components in hepatic cell lysosomes. J. Cell Biol., 12, 198-202.

Bachmann, K.-D. (1953). Uber das Lipofuscin der Leber. Virchows Arch, path. Anat, 323, 133-142.

Björkerud, S. (1964). Isolated lipofuscin granules-A survey of a new field. Advances Geront. Res., 1, 257-288.

- and Schelin, U. (1964). Liver changes in ceroid storage disease in childhood. Acta path. microbiol. scand., 60, 512-522.

Brody, H. (1960). The deposition of aging pigment in the human cerebral cortex. J. Geront., 15, 258-261.

Diezel, P. B. (1962). Die angeborenen Störungen des Lipoidstoffwechsels. Medizinische Grundlagenforschung. Band IV, pp. 239-297. G. Thieme, Stuttgart.

Eeg-Olofson, O., Kristensson, K., Sourander, P., and Svennerholm, L. (1966). Tay-Sachs disease, a generalized metabolic disorder. In manuscript.

Einarson, L., and Telford, I. R. (1960). Effect of vitamin-E deficiency on the central nervous system in various laboratory animals. Biol. Skr. Dan. Vid. Selsk., 11, no. 2.

Essner, E., and Novikoff, A. B. (1960). Human hepatocellular pigments and lysosomes. J. Ultrastruct. Res., 3, 374-391.

Friede, R. L (1962). The relation of the formation of lipofuscin to the distribution of oxidative enzymes in the human brain. Acta neuropath. (Berl.), 2, 113-125.

Gedigk, P., and Pioch, W. (1965). Uber die formale Genese lipogener Pigmente. Virchows Arch. path. Anat., 339, 100-135.

Gellerstedt, N. (1933). Zur Kenntnis der Hirnveränderungen bei der normalen Altersinvolution. Upsala Läk.-Fören. Förh., N.S., 38, 193-408.

Gilles, F. H. (1965). Pigment accumulation in the globus pallidus in childhood. Proc. Amer. Ass. Neuropath., 11-13 June, no. 24.

Gonatas, N. K., Terry, R. D., Winkler, R., Korey, S. R., Gomez, C. J., and Stein, A. (1963). A case of juvenile lipidosis: the significance of electron microscopic and biochemical observations of a cerebral biopsy. J. Neuropath. exp. Neurol., 22, 557-580.

Hamperl, H. (1934). Die Fluorescenzmikroskopie menschlicher Gewebe. Virchows Arch. path. Anat., 292, 1-51. 
Hydén, H. (1960). The neuron. In The Cell, edited by J. Brachet and A. E. Mirsky, vol. IV, ch. 5, p. 299. Academic Press, New York. and Lindström, B. (1950). Microspectrographic studies on the yellow pigment in nerve cells. Discussions Faraday Soc., 9, 436-441.

Issidorides, M., and Shanklin, W. M. (1961). Histochemical reactions of cellular inclusions in the human neurone. J. Anat. (Lond.), 95, $151-159$.

Kristensson, K., Rayner, S., and Sourander, P. (1965). Visceral involvement in juvenile amaurotic idiocy. Acta neuropath. (Berl.), 4, 421-424.

Neglia, W., Burrows, L., Thompson, S. W.; and Schaffner, F. (1963). Ultrastructural studies of hepatic pigment following administration of intravenous fat. Lab. Invest., 12, 378-385.

Obersteiner, H. (1912). Anleitung beim Studium des Baues der nervösen Zentralorgane, 5th ed. Deuticke, Vienna.

Pearse, A. G. E. (1960). Histochemistry, 2nd ed., p. 661. Churchill, London.

Sjövall, E. (1934). Die Bedeutung der pathologisch-histologischen Veränderungen im Zentralnervensystem bei der juvenilen amaurotischen Idiotie. Verh. dtsch. path. Ges., 27, 185-190.
Svennerholm, L., and Sourander, P. (1965). Combined histological and chemical investigation on brain autopsy material. In Proc. 5th int. Congr. Neuropath., Zürich.

Strehler, B. L., Mark, D. D., Mildvan, A. S., and Gee, M. V. (1959). Rate and magnitude of age pigment accumulation in the human myocardium. J. Geront., 14, 430-439.

Sulkin, N. M., and Srivanij, P. (1960). The experimental production of senile pigments in the nerve cells of young rats. Ibid., 15, 2-9.

Terry, R. D., and Weiss, M. (1963). Studies in Tay-Sachs disease. II. Ultra-structure of the cerebrum. J. Neuropath. exp. Neurol., 22, 18-55.

Wallace, B. J., Volk, B. W., and Lazarus, S. S. (1964). Fine structural localization of acid phosphatase activity in neurones of TaySachs disease. Ibid., 23, 676-691.

Zeman, W., and Albert, M. (1963). On the nature of the 'stored' lipid substances in juvenile amaurotic idiocy. Ann. Histochim., 8, 255-257.

Wolman, M. (1964). Lipid pigments. In Handbuch der Histochemie, band 5, teil 2: Lipide. pp. 92-132. Fischer, Stuttgart. 